\title{
6 \\ The Formation of a Land Grab Policy Network in Papua New Guinea
}

\author{
Colin Filer
}

\section{Introduction}

Papua New Guinea (PNG) possesses a very unusual—probably uniquelegal institution whose abuse lies at the heart of current public debate about land grabbing. This institution is commonly known as the leaseleaseback scheme. It was invented in 1979 in order to compensate for the absence of any other legal institution that would enable customary landowners to register titles to their own land. This absence was seen as an obstacle to rural development because 97 per cent of PNG's total land area was still customary land, and the ownership of this land was almost entirely illegible to the state and to private capital. The idea behind the lease-leaseback scheme was that groups of customary landowners could lease some of their land to the government, which would then create a formal title over it and lease it back to the landowners. The landowners would then have a piece of paper that they could use as security for a bank loan or as the basis for granting a sublease to a third party for some developmental purpose. The current legal form of the lease-leaseback scheme is represented in two sections of the Land Act. Section 11 says that the minister 'may lease customary land for the purpose of granting a special agricultural and business lease of the land', while Section 102 says that 
'a special agricultural and business lease shall be granted: (a) to a person or persons; or (b) to a land group, business group or other incorporated body, to whom the customary landowners have agreed that such a lease should be granted'. Section 11 also says that:

an instrument of lease in the approved form, executed by or on behalf of the customary landowners, is conclusive evidence that the State has a good title to the lease and that all customary rights in the land, except those which are specifically reserved in the lease, are suspended for the period of the lease to the State.

PNG is also unusual (if not exactly unique) in the propensity of its national government to reveal the dark underbelly of its own dysfunction through the establishment of commissions of inquiry and the eventual dissemination of their findings. The establishment of a commission of inquiry into the operation of the lease-leaseback scheme was announced by PNG's Acting Prime Minister, Sam Abal, in May 2011. In June, the National Executive Council (PNG's cabinet) formally endorsed its establishment and imposed a moratorium on the further grant of special agricultural and business leases (SABLs) and related licences until the Commission reported its findings to Parliament. Three senior lawyers, led by former Chief Magistrate John Numapo, were appointed as commissioners. The commissioners began their hearings in August 2011, and continued to gather evidence until March 2012. An interim report of their findings was presented to Prime Minister Peter O'Neill in March 2013, prompting him to voice his impatience over the length of time that was being taken to produce a final report (Nicholas 2013a). In response, the three commissioners cited a variety of political and bureaucratic obstacles that had hindered the progress of their work, but promised that a final report would be submitted by the end of April (Pok 2013). John Numapo and one of the other commissioners, Nicholas Mirou, submitted separate reports at the end of June (Mirou 2013; Numapo 2013), but the third commissioner, Alois Jerewai, refused to follow suit. When the Prime Minister tabled the two reports in Parliament in September 2013, he threatened 'disciplinary action' against all three commissioners (Nicholas 2013b). Commissioner Jerewai claimed that he had finished his own report in 2012, but he thought there should be one final report, co-authored by all three commissioners, and threatened legal action against all the other parties, including the Prime Minister and the other two commissioners, for failing to insist on this outcome (Kelola 2013). Nothing more was heard from him, and no 'disciplinary action' was taken. 
The interim report, the two final reports, and most of the transcripts of the hearings conducted by all three commissioners, were posted on the Prime Minister's departmental website at the end of November.

This chapter describes the formation of a land grab policy network as a two-stage process. The first stage is the one that led to the government's decision to establish the Commission of Inquiry in April 2011. The second stage is the one in which the network changed its shape during the period that elapsed between the start of the Commission's hearings and the public release of its findings. My account of this process is based on the information that I was able to gather in my own capacity as a participant observer. Other participants would no doubt tell a different story, but all such stories must necessarily be partial.

\section{The Network Assembled, 2008-2010}

The Commission's terms of reference made specific reference to a manifesto known as the 'Cairns Declaration', which had been produced in March 2011 by 'a large group of environmental and social scientists, natural resources managers and non-governmental organizations [sic] staff from Papua New Guinea and other nations [who] met in James Cook University in the city of Cairns, Australia to discuss the future management and conservation of Papua New Guinea's native forest'. At the same time, the terms of reference noted that ' $[\mathrm{m}]$ any segment [sic] of the community throughout the country, including civil society organisations, prominent leaders and landowner groups are increasingly objecting to SABL approval and management processes in recent times' (GoPNG 2011:2).

In a report later published by Greenpeace, Paul Winn also made reference to the Cairns Declaration, ${ }^{1}$ but assigned even greater significance to a please-explain letter that the PNG government had received from the UN Special Rapporteur on the Situation of Human Rights and Fundamental Freedoms of Indigenous People following a complaint lodged by PNG's Centre for Environmental Law and Community Rights and the UK-based Forest Peoples' Programme (Winn 2012: 15). By this account, the government was primarily responding to a campaign

1 Paul and I were both among the 26 signatories to the Cairns Declaration. 
organised by what I have previously called PNG's 'conservation policy community' (Filer 2005)—an interest group in which Greenpeace itself has long played a prominent role.

It seems rather unlikely that PNG's National Executive Council would have responded so rapidly and decisively to this kind of pressure if it had not been reinforced by pressure from other quarters over a longer period of time. Furthermore, such a decision would normally have to be based on a submission made by one or more cabinet ministers, and it is not obvious which ministers or departments would have taken this responsibility, nor is there any obvious reason why they would have been especially responsive to the arguments of conservationists. I suggest that the pressure came from a number of distinct interest groups that came to be joined up in a single policy network. One of the policy brokers who assembled this network is Paul Barker, the Director of PNG's Institute of National Affairs, which might best be described as a civil society thinktank. He was one of the first people to apply the phrase 'land grab' to the systematic abuse of the lease-leaseback scheme, and he did so in the title of a feature article published by one of PNG's national newspapers in May 2009. Paul Barker summarised his evidence as follows:

Over recent months about two million hectares of land across lowland provinces have been granted as Special Purpose Agricultural/Business Leases under the Land Act, with seven of these areas (in Western, Sepik, Central and Oro Provinces) each exceeding 100,000 hectares.

As with a 38,000 ha Collingwood Bay scam launched in 1995, and finally thrown out of court in 2001, many (if not all) of the 50 known schemes have apparently lacked due process, with landowners never granting their 'informed consent' for the State to lease their land and subsequently reallocate it to various named (largely overseas-controlled) interests (Barker 2009).

Members of the land grab policy network were essentially people who came to share the view that the land contained in SABLs of a certain size had indeed been 'grabbed', since it was not possible to imagine that the customary owners had given their free, prior and informed consent to the lease-leaseback process. However, it took some time for this network to be established, and it was never more than a 'rainbow coalition' of different interest groups. 


\section{The List of Dodgy Deals}

One thread in our story began with the appointment of Puka Temu as Minister for Lands and Physical Planning in January 2005. The new minister thought he had a mandate to discover more efficient and effective ways of mobilising customary land for urban and rural development. With this aim in mind, a National Land Summit was convened in August that year, and this was followed by the construction of a National Land Development Taskforce (NLDT) whose final report was ceremonially launched in February 2007. The 54 recommendations of the taskforce emerged from the deliberations of three different committees dealing with 'land administration', 'land dispute settlement', and 'customary land development'.

While Minister Temu later showed great enthusiasm for the leaseleaseback scheme as a means to 'mobilise' customary land, the report of the NLDT barely mentioned it - and then only to endorse its limited use by the existing oil palm industry (GoPNG 2007: 117). This is understandable, because the exponential growth in the number of large blocks of customary land alienated in this way had only just begun when the report was drafted in 2006. The taskforce was far more interested in plugging the legislative hole that had originally prompted the invention of the lease-leaseback scheme in 1979, and that was the absence of any legal mechanism by which incorporated groups of customary landowners could register formal titles to their land.

In August 2007, Brian Aldrich sent an email to Thomas Webster, with a copy to Pepi Kimas, expressing his concern about the number of SABLs that were being granted to private companies over large areas of customary land for the maximum allowable period of 99 years. Brian is a private land consultant and long-term PNG resident who had once worked as an expatriate contract officer in the Department of Lands and Physical Planning and was a member of the NLDT committee on land administration. Thomas Webster had been appointed to chair the NLDT in his capacity as Director of the National Research Institute, which is a government-funded think-tank accountable to the Minister for National Planning. Pepi Kimas was the Secretary of the Lands Department and had been a member of the NLDT committee on land dispute settlement. ${ }^{2}$

2 He had delegated one of his senior officers to participate in the central committee of the taskforce. 
Brian's interest in the issue derived from the fact that he had played a key role in helping the oil palm industry to establish 'mini-estates' on relatively small areas of customary land by arranging for SABLs to be granted to incorporated groups of customary landowners so that they in turn could issue subleases to the oil palm companies and receive a range of economic benefits in return. ${ }^{3}$ His view was that the Land Act should never have made provision for SABLs to be granted to anyone other than the families or land groups that had agreed to lease their land to the state in the first instance. His email included a table showing that 10 leases over a combined area of more than 270,000 hectares had been granted to private companies since October 2005. This was in fact an underestimate, since his reading of the National Gazette later led him to discover another 10 leases, with a combined area of roughly 130,000 hectares, which had been granted to private companies over the same period. So the area of concern already contained about 400,000 hectares of customary land that could have been alienated without the informed consent of the customary owners.

It is important to note here that the relevant notices in the National Gazette are somewhat mysterious, in the sense that they specify the size of the lease (in hectares), but they do not specify its actual boundaries, nor do they state how these relate to the boundaries of PNG's provinces and districts, which are the political entities represented by members of parliament. Instead, they make reference to portion numbers on a national collection of provincial land survey maps that are used to record the creation of formal land titles (see Figure 6.1). These maps are not readily available to members of the public, so even those few people, like Brian, who make it their business to read every issue of the National Gazette would not be able to tell where each of the leases was located. What Brian did was to construct a spreadsheet in which he recorded the date of each gazettal notice that struck him as being suspicious, and then recorded most of the other details of the lease in question in the other columns.

By his own account, Brian met with officers of the Lands Department in November 2007, and was assured that no more leases would be granted directly to private companies. However, by the time Secretary Kimas responded to Brian's original email, 12 months after it had been sent,

3 The mini-estates deserve their name because none of them covers more than 7,000 hectares of land. The total area covered by SABLs granted to local land groups for this purpose between 1998 and 2007 was less than 20,000 hectares. 
his officers had issued another 15 leases to private companies, with a combined area of more than 625,000 hectares, thus taking the total area covered by such transactions to more than 1 million hectares. At this juncture the Secretary stated that he would hold a meeting with his officers 'to address this issue further and to explore ways of informing the public of the potential risk involved'.

\section{Land Act No. 45 of 1996}

\section{NOTICE OF DIRECT GRANT UNDER SECTION 102}

I, Pepi S. Kimas, OL., Delegate of the Minister for Lands and Physical Planning, by virtue of the powers conferred by Section 102 of the Land Act No. 45 of 1996 and all other powers enabling me hereby directly grant a Special Agriculture and Business Lease to [A] over the land described in the Schedule hereunder.

1. The lease shall be used bona fide for the purpose specified in the Schedule.

2. The lease shall be for a term specified in the Schedule commencing from the date when the land was leased from the customary landowners to the State under Section 11 of the Land Act 1996.

3. The lease shall be rent-free for the duration of the lease.

4. Provision of any necessary easements for electricity, water, power, drainage and sewerage reticulations.

\section{SCHEDULE}

A Special Agriculture and Business Lease for a period of [number] years over all that piece of land known as "[B]" surveyed and legally described as Portion [number], Milinch of [C], Fourmil of [D] in [E] Province with an area of [number] hectares as registered on Survey Plan Catalogue No. [number].

Dated this [numbered] day of [month], [year].

P.S. KIMAS, OL., Delegate of the Minister for Lands \& Physical Planning.

Figure 6.1 Format of notices advertising the grant of special agricultural and business leases in the National Gazette.

Source: Author's rendition of common features of notices published in the National Gazette.

In an email sent to John Numapo shortly afterwards, Brian observed that no one appeared to be taking the issue seriously aside from himself and two other white men, Norm Oliver and Tony Power. John was at that time PNG's Chief Magistrate, and had chaired the NLDT committee on land 
dispute settlement. Norm was a former Land Titles Commissioner whom Brian had engaged to assist the oil palm industry in the establishment of 'mini-estates' by means of the grant of SABLs to incorporated land groups (Oliver 2001). Tony had long been an advocate for land group incorporation as a means of empowering customary landowners in the process of large-scale resource development (Power 2008), but also had a personal interest in the matter of current concern because land belonging to his wife's clan (in East Sepik Province) had already been included in an SABL granted to a foreign company. ${ }^{4}$

Brian continued to update and circulate his spreadsheet until it finally became the basis of the list of 72 leases, covering a total of 5.2 million hectares, which the Commission of Inquiry was directed to investigate when its terms of reference appeared in the National Gazette in July $2011 .^{5}$ By that time, the number of people who had seen at least one version of Brian's spreadsheet was much larger than it had been in 2008, but this new audience was not exactly his own creation. Once I started to receive copies of the spreadsheet in 2009, I noticed that he hardly ever sent them to more than three or four people, and although there were some variations in the identities of the recipients, there would not have been more than 10 recipients in the whole of that year. Thomas Webster was still one of them, but Pepi Kimas was not. Paul Barker was also one of the new recipients, and unlike Brian or Thomas, he was now prepared to turn the whole issue into a public scandal. If the land grab policy network therefore began to take a more public shape after the publication of his newspaper article in May 2009, who should be counted among its members by the end of that year?

\section{The Land Development Group}

At that juncture, it was possible to identify two distinct interest groups within the network, which I propose to call the 'land development group' and the 'oil palm industry group'. The land development group consisted of people who were actively involved in efforts to implement the recommendations of the NLDT, including some who had been

4 Neither Norm nor Tony had been members of the NLDT or any of its three committees, but could still be counted as members of the land grab policy network.

5 Brian's spreadsheet was never a complete list of all the SABLs granted to private companies, but it did include all of the leases that had been granted to private companies since 2003 and covered areas of more than 100 hectares. The Commission of Inquiry eventually dealt with 75 leases granted to private companies (Numapo 2013: 3). 
members of the taskforce itself or one of its three committees. In theory, this should have been quite a large group. The recommendations were now known as the National Land Development Program (NLDP), and this program was meant to have a Project Implementation Unit that reported to the Management Committee, which in turn reported to the Economic Ministerial Committee, which was a committee of the National Executive Council. In addition, there was meant to be a National Land Development Advisory Group (NLDAG) providing the Economic Ministerial Committee with independent advice on the implementation of the program (Levantis and Yala 2008). ${ }^{6}$ This organisational cluster should have come to life in 2008, but an 'implementation plan' produced by the Management Committee in 2010 revealed that little progress had been made by the end of 2009 except for the drafting of amendments to the Land Registration Act and the Land Groups Incorporation Act, both of which had been passed by the national parliament in March of that year (GoPNG 2008). This document also gave the impression that further progress would substantially depend on foreign aid funding that was yet to be made available. ${ }^{7}$

In these circumstances, it is hard to tell how many people were actively involved in efforts to implement the NLDP, how many of these people were bothered about the land grab unfolding in Brian's spreadsheet, and what, if anything, they were able to do about it. We now know that Thomas Webster and his colleagues at the National Research Institute were bothered about it. The same goes for John Numapo, who was still wrestling with the reform of PNG's land court system. And the same goes for Lawrence Kalinoe, who had chaired the NLDT committee on customary land development and then been appointed Secretary of the Constitutional and Law Reform Commission, in which capacity he had

6 The Management Committee was meant to include representatives from 'Magisterial Services, the National Research Institute, the Constitutional and Law Reform Commission, Office of Urbanization, Department of Justice and Attorney General, Department of Provincial and Local Government Affairs, the Department for Community Development, Department of Lands and Physical Planning, Department of Treasury and Department of Planning and Monitoring', while the Advisory Group was meant to include 'Vice Chancellor, UPNG; Head, Social Sciences and Humanities, UPNG; President, PNG Real Estate Association; Head, Land Studies Unit, UniTech; Director, Transparency International; Director, National Agriculture Research Institute; Director, Institute of National Affairs; Director, National Research Institute (Chairman); Chairman of PNG Rural industries Council; President of PNG Bankers' Association; President of PNG Chamber of Commerce and Industries; and the Chairman of PNG Association of NGOs' (GoPNG 2010a: 34-5).

7 The implementation plan was drafted by an Australian consultancy company called Land Equity International (see Chapter 14) and funded by the Australian aid program. 
drafted the legislation that would now enable customary landowners to register titles to their own land. However, these people were all public servants, and could not therefore give voice to their concerns in the same way as Paul Barker. Furthermore, it was now evident that Minister Temu, Secretary Kimas and most of the other officials in the Lands Department were not part of the land grab policy network but part of the problem that had to be solved, and despite the organisational complexity of the NLDP, officials in other government agencies had no more influence over the Lands Ministry than Paul or Brian had. And even if the NLDP had been implemented with greater speed, they were also hamstrung by the fact that it had nothing to say about measures to stop the abuse of the leaseleaseback scheme.

\section{The Oil Palm Industry Group}

Members of the oil palm industry group were bothered about the land grab because they realised that the lease-leaseback scheme was being abused by the proponents of so-called 'agro-forestry' projects. In PNG, the term 'agro-forestry' refers to the practice of clearing large areas of native forest on the pretext of making space for the cultivation of export crops and undertaking to use the revenues obtained from the export of raw logs to defray the cost of developing the plantation infrastructure. This idea originated in the 1990s as a device by which disreputable logging companies could circumvent the onerous regulations associated with the grant of selective logging concessions under PNG's 'sustainable forest management' regime. One of the earliest examples of the lease-leaseback scheme being used for this dubious purpose was the 'Collingwood Bay scam' mentioned in Paul Barker's feature article (Barker 2009), but this project had been blocked by legal action on the part of the customary landowners. The World Bank, in its capacity as one of the main architects of PNG's forest policy reforms, had also made strenuous efforts to block the legal loopholes through which such projects had occasionally gained some form of government approval (Filer 2000: 39-40).

The concept and practice of 'agro-forestry' received a new lease of life in 2005 when Michael Somare's government finally removed the World Bank from the forest policy process and hailed the dawn of a new 'green revolution' (Bonsella 2005). One of the earliest of the big SABLs in Brian's spreadsheet was the one issued to a company called Baina Agro-Forest Ltd in October of that year. This lease covered more than 40,000 hectares of 
land in Central Province and lasted for 40 years. Even before the SABL was gazetted, the president of the Forest Industries Association, Stanis Bai, was complaining that a logging company, Nasyl No. 98 Ltd, had 'illegally' entered the area on the false pretext of developing an oil palm estate (Anon. 2005a). This complaint was echoed by his brother, Brown Bai, who was chairman of the Rural Industries Council (Anon. 2005b). Their concerns seem to have been justified. The logging company managed to secure a log export licence in 2007 , exported a large quantity of logs in 2008, and then disappeared.

Despite the negative publicity that this project attracted in 2005, there was no mention of it in the NLDT report, even though a representative of the oil palm industry, Lillian Holland, was a member of the taskforce committee on land administration. Nevertheless, Mike Manning, who was a member of the central committee, and had preceded Paul Barker as Director of the Institute of National Affairs, voiced another public complaint about 'so-called agro-forestry projects' in September 2007. He did this in his capacity as chair of the PNG National Interpretation Working Group of the Roundtable on Sustainable Palm Oil (RSPO). This group was said to consist of 'all PNG's existing palm oil companies, the Oil Palm Industry Corporation, the PNG Oil Palm Research Association, the Department of Environment and Conservation, the Rural Industries Council and some environmental non-government organisations' (Anon. 2007).

The issue at stake here was that companies wishing to be members of the RSPO were obliged to prove that they were not responsible for the clearance of any new area of primary forest or destruction of ecosystems with high conservation value. Industry representatives were thus opposed to the new generation of agro-forestry projects-especially those that purported to be oil palm schemes- because of the risk they posed to its own reputation as a producer of 'sustainable' palm oil, even if the schemes proved to be illusory. Furthermore, the industry's own use of the leaseleaseback scheme was at risk of being tainted by association with land grabbers who had saved themselves the expense of securing the informed consent of customary landowners to a complex sequence of transactions that Brian Aldrich and Norm Oliver had shown to be required for the creation of new leasehold titles over relatively small areas of land (Filer 2012). 
Despite this demonstration of concern, the government proceeded to amend the Forestry Act at the end of 2007 in ways that made it harder for the National Forest Board to refuse the grant of what were now called 'forest clearing authorities' to the proponents of agro-forestry projects (McCrea 2009: 23). ${ }^{8}$ Once these amendments had been made, SABLs became the platforms from which landowner companies and their 'development partners' could launch their applications for such permits. That is why Paul Barker, who succeeded Mike Manning as chair of the National Interpretation Working Group, followed his feature article on the 'land grab' with a fresh complaint about the spread of oil palm development proposals that were "clearly not designed as viable "oil palm" projects' (Anon. 2009). Since Paul had many other hats to wear, the role of representing the oil palm industry in the land grab policy network then fell to Ian Orrell, another member of the working group who was then the head of PNG's Oil Palm Research Association but soon became the head of a new peak body called the PNG Palm Oil Council.

\section{The Silence of the Greens}

If the land development group and the oil palm industry group had both established themselves as key constituents of the land grab policy network by the end of 2009, very few members of the 'conservation policy community' appeared to have taken much interest in the issue. This seems rather odd, given that they had played such a prominent role in the defence of customary land rights against the first generation of agro-forestry project proposals, including the 'Collingwood Bay scam' (Seri 2005). Although Paul Barker was forwarding copies of Brian's spreadsheet to other members of the green community throughout the course of 2009, the response was muted.

When I wrote about the conservation policy community in 2005, I discussed the evidence of internal conflict between big international non-governmental organisations (NGOs) and their small local counterparts. Four years later, there was still evidence of a division, but I would now describe it as a split between the 'sustainability group' and the 'anti-dependency group'. Insofar as Paul and I belong to this policy community or network, we would count as members of the sustainability

8 The National Forest Board is the decision-making arm of the PNG Forest Authority. Its decisions are implemented by the staff of the National Forest Service. 
group because we think it is worthwhile to discuss the achievement of 'sustainable development outcomes' with representatives of the oil palm industry, the mining industry, or even the logging industry. Opponents of the anti-dependency group tend to describe it as an 'anti-development' group, in the hope or expectation that this label will subtract from its popular appeal, but members of this group say that they are only opposed to 'development' in the sense of sharing a belief that large-scale resource development is a bad thing because it induces a form of social and economic dependency at the same time that it causes serious environmental damage. The removal of the World Bank from PNG's forest policy process in 2005 was symptomatic of a change in the constitution of the conservation policy community, because foreign aid agencies and foreign NGOs had less money to spend on forest conservation projects. But if this changed the balance of power within the conservation policy community, it did not enable the anti-dependency group to wield any greater influence over any aspect of national government policy-whether it be forest policy, conservation policy or land policy. If anything, it had the opposite effect.

There was one environmental NGO, the Centre for Environmental Law and Community Rights (CELCOR), which had a representative on one of the NLDT's three special committees, and that was the committee on customary land development chaired by Lawrence Kalinoe. However, there is no evidence to indicate that CELCOR or any of the other organisations in the anti-dependency group endorsed the recommendations of that committee. On the contrary, a meeting of group members in July 2008 expressed strong opposition to the whole idea of registering group titles over customary land (Anon. 2008a). This was consistent with a common belief among members of this group that any legal device for the 'mobilisation' of customary land in Melanesia is the work of a neoliberal conspiracy masterminded by the World Bank and the Australian government (Anderson and Lee 2010), even though the architects of the taskforce had been at pains to exclude all foreign agencies from their deliberations (Levantis and Yala 2008). But it also reflected a total lack of trust in the capacity of the Lands Department to manage a process of registration without somehow turning it into a process of expropriation (Filer 2011a). Some members of the land development group might have felt the same way, but there was hardly any direct communication between the members of these two groups. 
Even so, one might have supposed that members of the anti-dependency group would have seized on the evidence contained in Brian's spreadsheet to bolster their case against the registration of customary land. Their initial failure to do so might best be explained by the scarcity of the resources at their disposal and their dedication to campaigns that distracted them from the implications of this evidence. One example of such distraction was the complaint that Damien Ase, CELCOR's executive director, lodged with the World Bank Inspection Panel in November 2009, in which he claimed that a project intended to provide support to smallholders in PNG's existing oil palm industry was in breach of several of the bank's safeguard policies. Given that CELCOR is an organisation whose stated mission is to provide legal assistance to 'landowners affected by large scale environmentally destructive projects including industrial logging, mining and oil palm plantation development' (Ase 2009: 1), it seems rather odd that disgruntled smallholders were still getting more of this assistance than the customary owners of huge tracts of land then being dedicated to the new generation of agro-forestry projects. It certainly seemed odd to members of the oil palm industry group in the land grab policy network.

\section{The REDD Distraction}

But in 2009, the biggest distraction of all was the chaos that surrounded the prospect of securing foreign investment in projects designed to reduce carbon emissions from deforestation and forest degradation. These so-called REDD (Reducing Emissions from Deforestation and Forest Degradation) projects had been a matter of interest to national policy makers since 2005, when Prime Minister Michael Somare made PNG one of the founding members of the Coalition for Rainforest Nations - an organisation dedicated to the aim of amending the United Nations Framework Convention on Climate Change in ways that would enable 'rainforest nations' to claim carbon credits from the international community. In 2009, a sort of climate policy group began to take shape as the fifth group in the land grab policy network, but it took such an odd sort of shape that it hardly qualified as a group with any sort of common interest.

The catalyst for the chaos was a notice published in the National Gazette at the end of April 2009, advising that a company called Tumu Timber Development Ltd (TTDL) had been granted an SABL over an area of almost 800,000 hectares in Western Province for a period of 99 years. 
Several members of the land grab policy network realised that this was the area known to the PNG Forest Authority as the Kamula Doso forest area. The anti-dependency group already had an interest in this area because one of its member organisations, the PNG Eco-Forestry Forum, had issued a legal challenge to a decision made by the National Forest Board to allocate this area to Rimbunan Hijau, PNG's biggest logging company, which already held an adjacent concession. This case was still before the courts. In the meantime, some members of the anti-dependency group and some government officials had separately decided that this would make an ideal site for a REDD project. Among the government officials was Theo Yasause, who had been appointed to head a new Office of Climate Change in the Prime Minister's Department in 2008. ' Yasause made some sort of arrangement with an Australian entrepreneur, Kirk Roberts, to market carbon credits from the Kamula Doso forest area, and Roberts sought the backing of an Australian carbon-broking company, Carbon Planet, for his own efforts to secure the backing of the TTDL board (Wood 2015).

Some members of the conservation policy community were already making complaints about this sort of arrangement in the middle of 2008 (Melick 2008). Their concerns were reflected in newspaper articles that complained about the state 'grabbing virgin forests' for REDD projects (Anon. 2008b), or warned of an invasion of 'speculators' and 'carpetbaggers' looking to make a fast buck out of the carbon business (Anon. 2008c). When TTDL was awarded its SABL in 2009, they readily assumed that this must be the work of Kirk Roberts and Theo Yasause. Shortly afterwards, the plaintiffs in the long-standing legal dispute over the area therefore asked the National Court to restrain the Lands Department from issuing the SABL on the grounds that Yasause had been wrong to grant carbon trading rights to Roberts. The Court then ordered both parties, along with the Minister for Lands and the Registrar of Land Titles, to be joined with Rimbunan Hijau and the PNG Forest Authority as defendants in the case. Following this order, the Eco-Forestry Forum issued a press release announcing that it had been successful in persuading the Court to grant 'injunctions to stop the Office of Climate Change and the Department of Lands from taking any further steps to issue rights over the forests of Kamula Doso' (PNGEFF 2009a).

9 This body was initially known as the Office of Climate Change and Carbon Trade, then as the Office of Climate Change and Environmental Sustainability. In 2010, it became the Office of Climate Change and Development. 
The assumption was later shown to be false. The TTDL board contained two different factions, one aligned with Roberts and one aligned with another Australian entrepreneur, Neville Harsley. It was Harsley who arranged the lease, and he had no interest in carbon trading, nor in the kind of agro-forestry project that was agitating the oil palm industry group. But key members of the conservation policy community had now decided to use the Kamula Doso 'carbon credits' as a weapon in their campaign to dislodge Yasause from his post. So they started to circulate evidence of his dealings to journalists whose connections ensured that it would make for an international scandal. In doing so, they made a second assumption that also proved to be false. They thought that Yasause must have been acting on instructions from PNG's 'climate change ambassador', Kevin Conrad, an American friend of the Somare family who was the real architect of the Coalition for Rainforest Nations. The reasoning was that Somare would not have put Yasause in charge of the Office of Climate Change without taking Conrad's advice. And since Conrad's remote control over PNG's climate policy process was a source of great annoyance to many members of the conservation policy community, there seemed to be a chance of killing two birds with one stone. But that did not happen. When the scandal broke, Yasause was removed from his post, official control of climate policy was restored to the Department of Environment and Conservation, and Kevin Conrad retained his own position of influence (Filer and Wood 2012; Filer 2015).

At this juncture, I was asked to advise the department on REDD matters in the lead-up to the United Nations climate change conference (the 15th 'conference of parties') to be held in Copenhagen at the end of the year. This was a source of additional annoyance to members of the Eco-Forestry Forum, who even went to the expense of publishing a full-page advertorial deploring my engagement (PNGEFF 2009b). The reason was that I had previously given advice to Carbon Planet on possible 'benefit sharing arrangements' for REDD projects in PNG, and was therefore thought to be one of the alien 'carbon cowboys' whose wicked schemes had been exposed and denounced in the media scandal that had gotten rid of Theo Yasause. The advertorial had no effect on Wari Iamo, the Secretary for Environment and Conservation, partly because he had already planned to seek my advice before his department lost its official control of climate policy in 2008, but mainly because he had been party to the 
National Forest Board's decision to allocate the Kamula Doso forest area to Rimbunan Hijau, and was therefore regarded as a public enemy by members of the anti-dependency group.

It was in fact my interest in REDD matters that led me to take an interest in Brian's spreadsheet at the start of 2009. In the advice that I provided to Carbon Planet in March that year, I observed that there was 'now some evidence that the lease-leaseback scheme has been subject to political manipulation of the sort feared by the opponents of customary land registration in 1995, and on a scale far greater than anything seen in the highland coffee industry or the current lowland oil palm industry', and that ' $[\mathrm{m}]$ any of these leases are of a size that would rule out any process of informed consent and participation on the part of the customary owners' (Filer 2009a: 24). I made the same point in my subsequent report to the Department of Environment and Conservation (Filer 2009b). Like my opponents in the conservation policy community, I was still under the impression that the SABL granted over the Kamula Doso forest area had somehow been organised by Kirk Roberts, and was therefore suggesting that the lease-leaseback scheme might not be the best way to secure large areas of customary land for REDD projects.

But there was also another issue here. It was already clear that most of the big SABLs were being engineered by the proponents of agro-forestry projects, not forest conservation projects. Since agro-forestry projects entail a substantial increase in the rate of deforestation, and not just in the sort of forest degradation associated with selective logging concessions, it was also reasonable to suggest that the approval of a new generation of agro-forestry projects might cause as much damage to PNG's reputation in the global climate policy domain as it was causing to the reputation of the existing oil palm industry in the global market for sustainable palm oil (Filer 2010). This was a point that I made to Secretary Iamo and his officers (Filer 2009c). The trouble was that he and his department had already been granting environment permits for these projects, and thus facilitating the subsequent grant of forest clearing authorities by the National Forest Board. If other members of the conservation policy community had been paying closer attention, they might have begun to wonder why such permits were being granted, especially when they required the approval of an independent Environment Council that was meant to review the environmental impact statements that were required under the terms of the Environment Act. 


\section{The Network Comes to Life}

Between the beginning and end of 2009, the area covered by the SABLs recorded in Brian's spreadsheet had grown from just over 1 million hectares to almost 2.5 million hectares. In January 2010, Paul Barker published a second feature article suggesting that the lease-leaseback scheme had been turned into a scam that was 'jeopardising landowners' customary rights over vast areas of the country, without their apparent informed consent' (Barker 2010). According to this article, the discretionary powers granted to the Lands Minister under Section 102 of the Land Act had been systematically abused, and the only way to remedy the situation would be to revoke these powers, cancel the leases that had been granted to private companies, and move ahead with the implementation of the new legislation that would enable customary landowners to register titles to their own land before granting leases to anyone else.

Paul attached a copy of this article, including the latest version of Brian's spreadsheet, to an email that he subsequently sent to 18 other members of the conservation policy community-mostly members of the anti-dependency group-in which he told them to 'get real', stop picking pointless fights with the World Bank and the existing oil palm industry, and start devising a strategy to 'ensure landowners are aware of issues, realities and options before these massive and often bogus new schemes are driven in' to their land. Paul's own strategy was to combine the SABL issue with the REDD issue and make both issues the subject of a multistakeholder workshop at the beginning of March that year. ${ }^{10}$ This was the first of several meetings that Paul organised with different groups of stakeholders involved in both of these issues over course of the following 12 months.

Meanwhile, Kevin Conrad seems to have persuaded the National Executive Council to engage McKinsey \& Company to develop PNG's climate change policy in the aftermath of the Copenhagen climate change conference. Indeed, they may well have started work on this subject before the end of 2009, since their initial proposal to the PNG government was made in June that year (Lang 2010), but they did not set up shop in the Environment Department until 2010. The McKinsey team had fairly limited contact with other members of the land grab

10 The costs of this meeting were largely borne by the Institute for Global Environmental Strategies based in Japan, and a focus on the REDD issue was probably a condition of this funding. 
policy network, but they were still quick to appreciate the argument that international funding for REDD projects would be harder to obtain if the PNG government appeared to be promoting an accelerated process of deforestation. ${ }^{11}$

In the second draft of their first policy document, the McKinsey team called for a moratorium to be imposed on the further grant of SABLs pending a review of the social and environmental impact of the country's agricultural development policies (GoPNG 2010b: 29). This document was endorsed by the National Executive Council soon after it was circulated in March 2010 (GoPNG 2010c: 2), and an Agriculture Sector Working Group was established to investigate the workings of the leaseleaseback scheme in the promotion of agro-forestry projects. Three of the four government agencies involved in the process sent representatives to the first of its meetings, but the Lands Department was notable by its absence (Valentine Thurairajah, personal communication, May 2010). ${ }^{12}$ The Interim Action Plan drafted by the McKinsey team and published by the newly reconstituted Office of Climate Change in August 2010 included an estimate of the amount of carbon emissions that could be avoided if forest clearing authorities were withdrawn from 60-80 per cent of the area (about 670,000 hectares) for which they had already been granted (GoPNG 2010c: 10).

In July 2010, the National Court finally issued a consent order reflecting the government's admission that the PNG Forest Authority had failed to secure the consent of the local landowners to the grant of a timber permit over the Kamula Doso forest area. This meant that the Eco-Forestry Forum was no longer distracted by the need to pursue that particular case. Meanwhile, some of the customary owners of other areas now covered by big SABLs had begun to seek help from the lawyers in the conservation policy community. These included the customary owners of an area in East New Britain Province where the proponent of an agro-forestry project

11 In February 2010, I worked with members of the McKinsey team to locate and digitise all of the environmental inception reports and environmental impact statements for agro-forestry projects that could be found on the shelves of the relevant section of the Environment Department - a total of 19 documents in all. This evidence made it possible to figure out the boundaries of the relevant leases, and also revealed the identities of the foreign companies involved in the projects. This in turn made it possible to hunt down the relevant company records held by the Investment Promotion Authority. At that time, we could not have known that all such information would eventually be tabled at the Commission of Inquiry.

12 This activity did at least result in the circulation of a document that showed that the National Forest Board had approved the grant of 14 forest clearing authorities by April of that year. 
proved to be none other than Rimbunan Hijau-public enemy number one for nearly all members of the anti-dependency group (Greenpeace 2004). ${ }^{13}$ So Paul Barker's call to arms could finally be answered by plans for a new round of litigation if funds could be raised to pay for it, and that was a hot topic in email conversation among members of the antidependency group in November 2010.

This conversation intensified in the wake of a meeting convened by members of the land development group at the National Research Institute, where Damien Ase produced the latest edition of Brian's spreadsheet and demanded to know what former members of the NLDT were going to do about it. In response, Lawrence Kalinoe, now Secretary for Justice, was reported to have said that the Lands Department was 'totally corrupt', because '[o]fficers and certain rouge [sic] landowners are colluding and conniving with each other to sell off customary land for their own benefit and interest while the majority of landowners are left out' (Joku 2010). In the same newspaper article, it was reported that Lawrence called for the department to be subject to a commission of inquiry in order to 'put it back on track'.

To the best of my knowledge, Lawrence was the first person to make this suggestion - at least in public —and it was he who drafted the relevant submission for his minister to present to the National Executive Council in 2011 (Lawrence Kalinoe, personal communication, February 2016). The McKinsey team also took an interest in this cabinet submission when they got wind of it in March that year. They asked me to work out which government ministers were likely to have a vested interest in one or more of the big SABLs that featured on Brian's spreadsheet. By matching the available spatial information to the boundaries of parliamentary electorates, I thought I could identify seven ministers who fell into this category, although Puka Temu was not one of them, because he had joined the ranks of the parliamentary opposition. I was therefore somewhat surprised when the Acting Prime Minister announced the decision to establish a commission of inquiry in May 2011.

13 Rimbunan Hijau obtained its forest clearing authority for this area in October 2010, but the company had announced its intention to develop at least one oil palm estate in PNG back in 2006 (Anon. 2006). 
As we have seen, the Commission's published terms of reference did point to the Cairns Declaration as a motivating factor, but they also stated that '[i]ssues surrounding SABL management are jeopardising PNG's chances of securing funding for REDD+ and combating climate change', and given PNG's position of leadership in global climate policy debates, the country 'must be seen to live by its words in respect of conserving forests to help reduce the green house gas emission [sic] and its effect on climate' (GoPNG 2011: 2). Kevin Conrad and the McKinsey team had no reason to say any more than this about their own role in the land grab policy network, since this would only have undermined the legitimacy of the Commission. ${ }^{14}$ And in any case, the cabinet decision may not have been wholly motivated by the appearance of a cabinet submission, but also by the appearance of a groundswell of public protest facilitated by other members of the network, including the urban representatives of specific rural communities whose land had been expropriated (Filer 2011b).

\section{The Network Reassembled, 2011-2013}

The first step in the transformation of the land grab policy network was a radical change in the position of the climate policy group as one of its distinctive elements. Kevin Conrad and the McKinsey team disappeared from the network in August 2011, when the national parliament voted to remove Michael Somare from office and elect Peter O'Neill as his replacement. This did not spell the end of the Office of Climate Change, but the position of that agency was compromised by the decision that it should henceforth be accountable to Belden Namah. Namah had been the Forests Minister who sponsored the 2007 amendments to the Forestry Act, and had subsequently taken advantage of these amendments to secure a forest clearing authority for a very large agro-forestry project in his own electorate. He had been outraged by the decision to establish a commission of inquiry, and might well have taken it as a personal attack, since he had just been elected Leader of the Opposition at the time of its announcement. The price of his support for O'Neill's move against Somare was the position of Deputy Prime Minister, Minister for

14 It is equally understandable that the Greenpeace account of what happened also made no reference to their involvement, since Greenpeace has no time for the McKinsey method of calculating the economic costs and benefits of forest carbon sequestration (Greenpeace 2011). 
Forests, and Minister for Climate Change. While his occupation of these positions enabled him to get rid of the Conrad-McKinsey group, they did not enable him to interfere with the inquiry.

Following the national elections of July 2012, O'Neill was able to assemble a governing coalition without the support of Namah, who returned to his former role as Leader of the Opposition. The Office of Climate Change was still accountable to the new Forests Minister, Patrick Pruaitch, but its officials no longer had much reason to worry about the findings of the Commission of Inquiry, nor did they have much capacity to influence the government's response. Although they were still charged with the task of producing legislation that would regulate foreign investment in forest carbon projects, it was already evident that the lease-leaseback scheme would not be part of this legal framework. The McKinsey team had left behind a number of policy documents and a very fine suite of PowerPoint slides, but while the legislative task was still unfinished, the Forestry Act remained the most appropriate legal instrument for the control of deforestation and forest degradation. Officials in the National Forest Service therefore included some carbon emission reduction proposals in the latest draft of the National Forest Plan (GoPNG 2012), but discussion of such activities seemed increasingly remote from the debate about what should be done with agro-forestry projects. That is because most members of the land grab policy network now realised that there was no immediate prospect of anyone harvesting a large amount of foreign carbon finance from decisions of the National Forest Board to withhold, revoke or suspend the grant of forest clearing authorities.

While members of the conservation policy community retained some interest in the question of how customary landowners might benefit from a new generation of forest conservation projects, members of the antidependency group were now convinced that the new generation of agroforestry projects was simply the logical extension of a process by which the destruction of native forests was intimately tied to the corruption of the state. As news of the Commission's hearings percolated through the media, evidence of corporate and bureaucratic misbehaviour was used to garner additional international support for a domestic campaign against the foreign capitalists who had supposedly conspired with their local political cronies to undermine the rule of law and deprive innocent customary landowners of their constitutional rights. The amplification of this message entailed a simplification of the problem of consent that the Commission had been asked to investigate. Customary landowners 
in their right minds could not possibly consent to the theft of their own property, so the state must have been corrupted in a way that enabled the country's political elite to steal the property of their fellow citizens and sacrifice it to the foreign devils of resource development. So the leaseleaseback scheme was just the latest manifestation of the resource curse that had bewitched the nation.

The amplification and simplification of this message did not allow for any further debate about the relative merits of different foreign devils. It made more sense to portray them all in the same bad light, and even to link them together as members of a single community or conspiracy. Greenpeace was the first foreign organisation to support the campaign against the land grab because of the discovery that its old enemy, Rimbunan Hijau (RH), was one of the companies engaged in the practice of agro-forestry. This made it possible for the anti-dependency group to claim that RH must somehow have masterminded the abuse of the leaseleaseback scheme, just as it was previously thought to have exercised some sort of monopoly over PNG's selective logging industry during the forest policy reform process of the 1990s (Filer 1997, 2013). To consolidate this impression, Greenpeace mounted a seaborne expedition to collect evidence of popular discontent at the site of the company's agro-forestry project in East New Britain. This event was carefully timed to coincide with the hearings that Alois Jerewai conducted in that province in October 2011 (see Chapter 7, this volume).

In the blaze of publicity that accompanied this confrontation, the company protested that it was not responsible for any of PNG's other agro-forestry projects, its own project had the full support of the provincial government and most of the local landowners, so it did not deserve this level of critical attention (Gabriel 2015). We do not know what Jerewai would have said about this project in the final report that he did not submit to the Prime Minister, but John Numapo's final report includes an assertion that more than half of the companies holding subleases from the holders of SABLs were 'connected in one way or another' to RH (Numapo 2013: 242). This statement was music to the ears of some members of the antidependency group (Act Now 2014a), but it was not warranted by the evidence contained in the transcripts of the hearings conducted by all three commissioners. It is true that $\mathrm{RH}$ was found to have some sort of connection to several of the leases that were investigated, but certainly not to half of them, and most of those with which it did have some connection had not become the sites of actual agro-forestry projects. The records of 
the PNG Forest Authority indicate that RH held only one of the 22 forest clearing authorities that are known to have been granted before the Commission was established, and this was indeed the one that had been granted for the Sigite-Mukus project in East New Britain.

Greenpeace published its own report on the land grab in August 2012 (Winn 2012), shortly after the national elections that enabled Peter O'Neill to consolidate his grip on political power. The report made good use of the evidence presented in some of the Commission's hearings, but it was hard to assess its likely influence on the government's future response to the commissioners' recommendations. My own concern, shared with some other members of the land grab policy network, was that the government might play the national sovereignty card when confronted with a radical populist campaign in which foreign voices made much of the noise. However, the Papua New Guinean members of the antidependency group needed money to fund their own domestic campaign, so they stuck to the strategy of broadening their international support network in order to avoid being tainted by association with any part of PNG's private sector, let alone its politicians and public servants.

The next foreign organisations to add their own voices to the campaign were the California-based Oakland Institute and the Fiji-based Pacific Network on Globalisation, whose representatives teamed up with several members of the anti-dependency group to produce another account of the corruption unveiled by the Commission of Inquiry. Their evidence was collected in March 2013, around the time that the commissioners were presenting their first interim report to the Prime Minister, and their own report was published in November 2013, just before the Commission's two final reports were placed in the public domain. Their report did not add much of substance to the information already contained in previous publications, including the Greenpeace report, but was interesting primarily because of its argument that the amount of customary land 'in the hands of foreign corporations' was much greater that the amount covered by SABLs granted to private companies (Mousseau 2013: 4), and the subsequent argument that agro-forestry projects ought to be resisted because of the negative social and environmental impact of the existing oil palm industry (ibid.: 18). The first argument seems to assume that the lease-leaseback scheme did not involve a more complete form of expropriation than the legal arrangements by which customary landowners have agreed to alienate their timber harvesting rights for the purpose of creating selective logging concessions, while the second argument seems 
to imply that selective logging, forest clearance and the development of oil palm estates are all equally destructive if carried out on a large scale, so the failure of agro-forestry projects to develop oil palm estates with the proceeds of forest clearance might actually be a good thing.

The Pacific Network on Globalisation later added another twist to this line of argument by suggesting that the World Bank was implicated in the PNG land grab because its 'ease-of-doing-business' index had encouraged the government to deregulate the land acquisition process (Act Now 2014b). The idea that the World Bank, RH and New Britain Palm Oil Ltd were the three key players in a global conspiracy to expropriate the poor peasants of PNG might have some appeal to academic anarchists (Anderson 2011, 2015), but it does not reflect the history of forest policy reform in PNG, nor was it likely to influence the direction of the policy process that would follow on from the Commission of Inquiry. Members of the other three groups in the land grab policy network-the oil palm industry group, the land development group and even the sustainability group-were not concerned with the question of how to reverse the alienation of all customary land rights, but rather with the more specific questions addressed by the Commission itself, which was how to rectify the abuse of the lease-leaseback scheme and how to ensure that such abuse could not be repeated in future.

Members of the oil palm industry group continued to gather evidence about the economic credentials of companies that had been granted forestclearing authorities, and other companies that showed an interest in the future development of agro-forestry projects, even during the period in which the findings of the Commission had not yet been released. They also continued to monitor the progress of existing projects that promised the eventual production of palm oil in order to assess the likelihood that this promise would be kept. The National Forest Board also made some effort to monitor the compliance of existing projects with conditions attached to their forest clearing authorities and, in some cases, this led to a temporary suspension of the permits because the area that had been cleared was too far in excess of the area that had been planted with cash crops. The commissioners also took an interest in such matters, but it was not clear how evidence of this kind might eventually be used to justify the cancellation of the SABLs granted to landowner companies that had then issued subleases to the foreign investors who were clearing the forest. 
Some of the senior government officials who were members of the land grab policy network were more concerned by the possibility that the state would be liable to pay these investors substantial amounts in damages if the SABLs were to be cancelled (Lawrence Kalinoe, personal communication, July 2013). Even if the investors had colluded in the process by which the original leases were granted, it might be hard to prove this in court, and if other government officials had already helped the investors to get their hands on the land, they might now help them to get their hands on a financial reward for the opportunity cost of losing control of it. ${ }^{15}$ The particular case that prompted this concern was one brought by a company called Albright Ltd, which had entered into a sublease agreement with a landowner company called Mekeo Hinterland Holdings Ltd after the latter had been granted an SABL over a large area of land in Central Province. This SABL was nullified by a decision of the National Court at the end of 2010, before the Commission of Inquiry was established, but in March 2012, Albright claimed damages of more than K153 million from the landowner company and the government, and initially secured a default judgement in its favour when the state failed to file a defence. In July 2013, the state defendants returned to the National Court with a request for this judgement to be set aside on the grounds that they had no 'actionable statutory duty' towards Albright in respect of the sublease agreement. The Court agreed with this argument, ${ }^{16}$ but Albright was given leave to appeal to the Supreme Court, and the appeal was finally rejected in May $2014 .{ }^{17}$

Even though the outcome of this case seems to confirm the power of the National Court to cancel SABLs without creating additional financial liabilities for the state, it is not so clear that the National Executive Council or the Lands Minister could exercise the same power in the absence of a case brought by a group of disaffected landowners, and such cases have so far been relatively rare. One such case arose from the decision of the Lands Department to grant a couple of SABLs to landowner companies in Oro Province in July 2012, in apparent defiance of the moratorium imposed when the Commission of Inquiry had been established. It soon transpired that these leases covered the same area that

15 The role of government officials in aiding and abetting spurious compensation claims against the state had been the subject of a previous commission of inquiry into the Department of Finance (Sheehan et al. 2009).

16 Albright Ltd v Mekeo Hinterland Holdings Ltd [2013] PGNC 262.

17 Albright Ltd v Mekeo Hinterland Holdings Ltd [2014] PGSC 30. 
had been covered by the SABLs previously granted to another landowner company in the 1990s, which formed the basis for what Paul Barker called the 'Collingwood Bay scam' (Barker 2009). The original leases had been revoked by an order of the National Court in 2002, before the Lands Department began to grant any of the SABLs that the commissioners were investigating. Nevertheless, Thomas Webster took this latest action as proof that the Lands Department was incorrigible, while the landowners who had got the National Court to cancel the original leases were now faced with the prospect of having to engage in a fresh round of legal action to obtain the same result (Pok 2012a, 2012b). They finally won this second battle in May 2014, around the same time that Albright finally lost its compensation claim. Although their victory had no direct bearing on the question of what the government should do with the Commission's recommendations, the case was still significant because the legal action had been backed by the newly elected Governor of Oro Province, Gary Juffa, who declared that there was nothing to prevent members of parliament or provincial governments from taking such action to defend the rights of their constituents (Miae 2014).

The second iteration of the 'Collingwood Bay scam' had a somewhat different significance for members of the land development group and the oil palm industry group. When Thomas Webster deplored the misbehaviour of the Lands Department, he observed that such action was not only a breach of the moratorium imposed by the National Executive Council, but should have been rendered redundant by the fact that customary landowners could now register titles to their own land and issue their own leases to developers of their choice without any need to resort to the chicaneries of the lease-leaseback scheme (Pok 2012a). That is because the amendments to the Land Registration Act and the Land Groups Incorporation Act that had been passed by the national parliament in March 2009 had actually been certified and gazetted in February 2012, shortly before the Commission of Inquiry got to the end of its hearings. However, this legislation posed a new problem because of its requirement that all of the existing land groups in the country, including those that had participated in the lease-leaseback scheme, should undergo a complex process of reincorporation within a period of five years in order to retain their legal status. Only those groups that were incorporated or reincorporated under the amended version of the Land Groups Incorporation Act would be allowed to register titles to their land under the amended version of the Land Registration Act. A new 
world of properly constituted land groups with registered land titles was one of the ideals of the NLDP, but that program's machinery had almost ground to a halt since the establishment of the Commission of Inquiry, so the implementation of the new legislation was now the responsibility of a Lands Department whose failings had been documented in minute detail.

\section{Conclusion}

A commission of inquiry is one phase in the process by which public scandals generate new policies, laws and institutions. The formation of a policy network is one aspect of this process. The number of people and range of interests represented in the network will normally reflect the magnitude of the scandal that starts the process and the amount of time and effort spent on the reforms that bring it to an end. But political cycles of this type do not always run their course in isolation from each other, nor are they always immune from interference by other changes in the political landscape.

The direction of the process started by the land grab scandal has been affected by that of two previous cycles containing their own commissions of inquiry. One was an inquiry into the regulation of the logging industry, whose findings and recommendations started a process of forest policy reform in 1989 (Barnett 1989, 1992); the other was an even earlier inquiry into the regulation of land tenure, whose findings and recommendations started a process of land policy reform in 1974 (GoPNG 1973; Ward 1983). If the recommendations for land policy reform had been implemented in a timely fashion, there would have been a legal avenue for the registration of customary group titles before the end of the 1970s, and the lease-leaseback scheme would never have been invented. The process of forest policy reform did not result in a legal and institutional framework that was quite so obviously incomplete, but it did produce a situation in which the World Bank and its national allies struggled to defend the new framework against the sort of scandalous behaviour that led to that commission of inquiry (Filer 2000; Forest Trends 2006). 
The two cycles were briefly entangled in 1995, when the World Bank's investment in forest policy reform was compromised by rumours that it was also in the business of 'stealing the people's land' because it had made a parallel investment in completion of the land policy reform process initiated by the earlier commission of inquiry (Filer 2000: 32-7). This is the point at which the anti-dependency group made its first appearance on the national political stage as a group of people who were equally opposed to the registration of customary land titles and to any industrial exploitation of customary land. But the fuss they made at the time was also the reason why members of the land development group insisted on excluding the World Bank and other members of the 'donor community' from the appearance of any involvement in the next attempt to start finishing the land policy reform process in 2005.

If World Bank staff had any cause for disappointment over this act of exclusion, it would not have matched the frustration caused by their simultaneous exclusion from the cycle of forest policy reform. That wheel soon turned full circle, when amendments to the Forestry Act made it easier for the lease-leaseback scheme to become the site of a new scandal. But this new point of intersection between the cycles of land and forest policy reform had more chaotic effects than the momentary (and largely fabricated) scandal of 1995. Here we had a national conference (the National Land Summit) that was convened to deal with the problems that had arisen from the implementation or non-implementation of the recommendations made by a commission of inquiry more than three decades beforehand. The conference led to the creation of a taskforce (the National Land Development Taskforce) that produced a program of policy reform (the National Land Development Program) whose implementation was rudely interrupted by a new scandal that led to a new commission of inquiry. As a result, the land grab policy network assembled a couple of groups that originated in the process of forest policy reform, a couple of groups that originated in the process of land policy reform, and one group — the climate policy group — that had not been part of either process until the scandal broke. So the process generated by this scandal was almost bound to be a sort of hybrid policy process in which it would not be possible to reconcile the interests of all these different groups in one new package of policies, laws and institutions. The resulting stalemate is explored in Chapter 8. 


\section{References}

Act Now (for a Better Papua New Guinea), 2014a. 'Rimbunan Hijau, the SABL Puppeteer.' Blogpost by 'rait man', 23 January. Viewed 12 October 2016 at: www.actnowpng.org/content/rimbunan-hijausabl-puppeteer.

—, 2014b. 'PANG supports demand for World Bank to end its support for resource grab.' Blogpost by 'Elizabeth1', 6 May. Viewed 12 October 2016 at: www.actnowpng.org/content/pang-supportsdemand-world-bank-end-its-support-resource-grab.

Anderson, T., 2011. 'Melanesian Land: The Impact of Markets and Modernisation.' Journal of Australian Political Economy 68: 86-107.

—, 2015. Land and Livelihoods in Papua New Guinea. Melbourne: Australian Scholarly Publishing.

Anderson, T. and G. Lee (eds), 2010. In Defence of Melanesian Customary Land. Sydney: Aid/Watch.

Anon., 2005a. 'Call to Revoke Logger's Licence.' Post-Courier, 26 September.

— , 2005b. 'Concern over Loggers' Promises.' Post-Courier, 17 October.

— 2006. 'RH Moves into Oil Palm.' Post-Courier, 6 June.

—_, 2007. 'Govt Hits Oil Palm Hurdle.' Post-Courier, 11 September.

_ 2008a. 'National Land Development Taskforce Report: NGO Response.' Unpublished typescript.

_ , 2008b. 'State “Grabs” Forest for REDD.' Post-Courier, 31 October.

—, 2008c. 'Carbon Trading or Carpet Baggers.' Post-Courier, 22 November.

_ 2009. 'New Palm Oil Firms “a Concern”.' The National, 25 June.

Ase, D., 2009. 'Request for Inspection: Smallholder Agricultural Development Project-Papua New Guinea.' Port Moresby: Centre for Environmental Law and Community Rights.

Barker, P., 2009. 'Land Grab-A Sinister Cycle.' Post-Courier, 11 May. 
__, 2010. 'Land Rights Vital.' Post-Courier, 7 January.

Barnett, T.E., 1989. Report of the Commission of Inquiry into Aspects of the Forest Industry: Final Report (2 volumes). Port Moresby: Unpublished report to the Government of PNG.

__ 1992. 'Legal and Administrative Problems of Forestry in Papua New Guinea.' In S. Henningham and R.J. May (eds), Resources, Development and Politics in the Pacific Islands. Bathurst (NSW): Crawford House Press.

Bonsella, B., 2005. 'PM: Green Revolution to Boost Economy by 5pc.' The National, 25 July.

Filer, C., 1997. 'A Statistical Profile of Papua New Guinea's Log Export Industry.' In C. Filer (ed.) The Political Economy of Forest Management in Papua New Guinea. Port Moresby: National Research Institute (Monograph 32).

—_, 2000. The Thin Green Line: World Bank Leverage and Forest Policy Reform in Papua New Guinea. Port Moresby and Canberra: National Research Institute and The Australian National University.

—_, 2005. 'The Conservation Policy Community in Papua New Guinea.' Canberra: The Australian National University, Research School of Pacific and Asian Studies, Resource Management in AsiaPacific Program (Working Paper 55).

—_, 2009a. 'Institutional Mechanisms for Establishment and Management of Forest Carbon Sequestration Projects in Papua New Guinea.' Unpublished report to Carbon Planet Ltd.

__, 2009b. 'Land Rights and Benefit Sharing Arrangements for REDD Projects in Papua New Guinea.' Port Moresby: Unpublished report to PNG Department of Environment and Conservation.

__ 2009c. 'Drivers of Deforestation and Forest Degradation in Papua New Guinea.' Port Moresby: Unpublished report to PNG Department of Environment and Conservation.

__ 2010. 'Impacts of Rural Industry on the Native Forests of Papua New Guinea.' Pacific Economic Bulletin 25(3): 135-153. 
—_, 2011a. 'New Land Grab in Papua New Guinea.' Pacific Studies 34: 269-294.

_ 2011b. 'The New Land Grab in Papua New Guinea: A Case Study from New Ireland Province.' Canberra: The Australian National University, College of Asia and the Pacific, State Society and Governance in Melanesia Program (Discussion Paper 2011/2).

—, 2012. 'Why Green Grabs Don't Work in Papua New Guinea.' Journal of Peasant Studies 39: 599-617. doi.org/10.1080/03066150. 2012.665891.

_ 2013. 'Asian Investment in the Rural Industries of Papua New Guinea: What's New and What's Not?' Pacific Affairs 86: 305-326. doi.org/10.5509/2013862305.

—_, 2015. 'How April Salumei Became the REDD Queen.' In J.A. Bell, P. West and C. Filer (eds), Tropical Forests of Oceania: Anthropological Perspectives. Canberra: ANU Press.

Filer, C. and M. Wood, 2012. 'The Creation and Dissolution of Private Property in Forest Carbon: A Case Study from Papua New Guinea.' Human Ecology 40: 665-677. doi.org/10.1007/s10745-012-9531-2.

Forest Trends, 2006. Logging, Legality and Livelihoods in Papua New Guinea: Synthesis of Official Assessments of the Large-Scale Logging Industry. Jakarta: Forest Trends.

Gabriel, J., 2015. 'Evergreen" and REDD+ in the Forests of Oceania.' In J.A. Bell, P. West and C. Filer (eds), Tropical Forests of Oceania: Anthropological Perspectives. Canberra: ANU Press.

GoPNG (Government of Papua New Guinea), 1973. Report of the Commission of Inquiry into Land Matters. Port Moresby: GoPNG.

- 2007. The National Land Development Taskforce Report: Land Administration, Land Dispute Settlement, and Customary Land Development. Port Moresby: National Research Institute (Monograph 39).

— 2008. 'Review of Incorporated Land Groups \& Design of a System of Voluntary Customary Land Registration.' Port Moresby: Constitutional and Law Reform Commission. 
__ 2010a. 'Papua New Guinea National Land Development Program Phase 1 (2011-2015): Implementation Plan.' Port Moresby: National Land Development Program Management Committee.

__, 2010b. 'Climate-Compatible Development for Papua New Guinea: Second Draft—for Stakeholder Comment.' Port Moresby: Department of Environment and Conservation.

___, 2010c. 'Interim Action Plan for Climate-Compatible Development.' Port Moresby: Office of Climate Change and Development.

__, 2011. 'Commission of Inquiry into the Management Generally of the Special Agriculture and Business Leases and All Matters Relating to the Special Agriculture and Business Leases: Statement of Case.' Port Moresby: National Gazette G198.

__ 2012. 'National Forest Plan (Draft).' Port Moresby: PNG Forest Authority.

Greenpeace, 2004. 'The Untouchables: Rimbunan Hijau’s World of Forest Crime \& Political Patronage.' Amsterdam: Greenpeace International.

—_, 2011. 'Bad Influence: How Mckinsey-Inspired Plans Lead to Rainforest Destruction.' Amsterdam: Greenpeace International.

Joku, H., 2010. 'Lands Dept “Corrupt”.' Post-Courier, 11 November.

Kelola, T., 2013. 'Jerewai Hits Back.' Post-Courier, 18 September.

Lang, C., 2010. 'Mckinsey's REDD Plans in Papua New Guinea: Nice Work If You Can Get It.' REDD Monitor blogpost, 7 October. Viewed 5 October 2016 at: www.redd-monitor.org/2010/10/07/ mckinseys-redd-plans-in-papua-new-guinea-nice-work-if-you-canget-it/\#more-5966.

Levantis, T. and C. Yala, 2008. 'Breaking Away from the Land Policy Stalemate.' Pacific Economic Bulletin 23(1): 99-110.

McCrea, P., 2009. 'Oil Palm Sector Situation and Perception Assessment: Papua New Guinea.' Port Moresby: Unpublished report to World Bank and Oil Palm Industry Corporation. 
Melick, D., 2008. 'On-the Ground Role of NGOs with Emerging Carbon Market Issues: Is the REDD Emperor Actually Wearing Any Clothes?' Paper presented to seminar on 'Challenges to the National Implementation of Activities to Reduce Emissions from Deforestation and Forest Degradation (REDD)', The Australian National University, Canberra, 18 June.

Miae, E., 2014. 'Landowners Get Leases Cancelled.' The National, 23 May.

Mirou, N., 2013. Commission of Inquiry into Special Agriculture and Business Lease (C.O.I. SABL): Report. Port Moresby: Government of Papua New Guinea. Viewed 5 October 2016 at: www.coi.gov.pg/ documents/COI\%20SABL/Mirou\%20SABL\%20Final\%20Report.pdf.

Mousseau, F., 2013. 'On Our Land: Modern Land Grabs Reversing Independence in Papua New Guinea.' Oakland (CA): The Oakland Institute in collaboration with Pacific Network on Globalisation.

Nicholas, I., 2013a. 'Disappointment over No SABL Report.' Post-Courier, 27 March.

—, 2013b. 'Trio Referred.' Post-Courier, 13 September.

Numapo, J., 2013. Commission of Inquiry into the Special Agriculture and Business Lease (SABL): Final Report. Port Moresby: Government of Papua New Guinea. Viewed 5 October 2016 at: www.coi.gov. $\mathrm{pg} /$ documents/COI\%20SABL/Numapo\%20SABL\%20Final\%20 Report.pdf.

Oliver, N., 2001. 'Lease, Lease-Back: An Instrument for Forestry?' In C. Hunt (ed.), Production, Privatisation and Preservation in Papua New Guinea Forestry. London: International Institute for Environment and Development.

PNGEFF (Papua New Guinea Eco-Forestry Forum), 2009a. 'Press Release: Court Stops Carbon Deal.' Port Moresby: PNGEFF.

— 2009b. 'EFF Calls on Government of PNG, Development Partners and AusAid to Help Protect PNG from Carbon Scams.' Islands Business 35(10).

Pok, J., 2012a. 'SABL Abuses Must Be Dealt with Strongly.' Post-Courier, 5 September. 
—_, 2012b. 'Oro SABL’s Queried.' Post-Courier, 14 September.

__, 2013. 'Shut Up!' Post-Courier, 28 March.

Power, T., 2008. 'Incorporated Land Groups in Papua New Guinea.' In AusAID (Australian Agency for International Development) (ed.), Making Land Work -Volume Two: Case Studies on Customary Land and Development in the Pacific. Canberra: AusAID.

Seri, L., 2005. 'Land Defrauders: A Close Call.' Post-Courier, 19 April.

Sheehan, M., C. Davani and D. Manoa, 2009. The Commission of Inquiry Generally into the Department of Finance: Final Report. Port Moresby: Government of Papua New Guinea.

Ward, A., 1983. 'The Commission of Inquiry into Land Matters 1973: Choices, Constraints and Assumptions.' Melanesian Law Journal 11: $1-13$.

Winn, P., 2012. 'Up for Grabs: Millions of Hectares of Customary Land in PNG Stolen for Logging.' Sydney: Greenpeace Australia Pacific.

Wood, M., 2015. 'Representational Excess in Recent Attempts to Acquire Forest Carbon in the Kamula Doso Area, Western Province, Papua New Guinea.' In J.A. Bell, P. West and C. Filer (eds), Tropical Forests of Oceania: Anthropological Perspectives. Canberra: ANU Press. 
This text is taken from Kastom, property and ideology: Land transformations in Melanesia, edited by Siobhan McDonnell, Matthew Allen and Colin Filer, published 2017 by ANU Press, The Australian National University, Canberra, Australia. 